Frontiers: The Interdisciplinary Journal of Study Abroad Volume 32, Issue 2, pp. 1-11

(C) Amelia J. Dietrich

This work is licensed under the Creative Commons Attribution-NonCommercial-

NoDerivatives 4.0 International License.

DOI 10.36366/frontiers.v32i2.465

THE

FORUM

ON EDUCATION

ABROAD

\title{
Charting a Path Forward for Education Abroad Research
}

Amelia J. Dietrich ${ }^{1,2}$

\begin{abstract}
This article briefly reviews the most important and impactful research published in the journal Frontiers: The Interdisciplinary Journal of Study Abroad over the course of its first 25 years of publication and looks ahead to the research directions that can help the field move past the negative effects of COVID-19 and prepare for its next transformation. Goals are set for the future of education abroad as a field of both scholarly inquiry and professional practice.
\end{abstract}

\section{Abstract in Spanish}

Este artículo repasa brevemente la investigación más importante e impactante que ha sido publicado en la revista Frontiers: The Interdisciplinary Journal of Study Abroad durante los primeros 25 años de su publicación y mira hacia el futuro para identificar las direcciones de investigación que podrán servir para la recuperación del campo de estudios en el extranjero después de COVID-19. El artículo identifica metas para el futuro de la educación en el extranjero como campo de investigación académica y como práctica profesional.

\section{Keywords:}

education abroad, study abroad, global citizenship, global learning, international education, COVID-19

${ }^{1}$ Managing Editor, Frontiers: The Interdisciplinary Journal OF StUdy AbroAd, CARLisLe, PA, USA

${ }^{2}$ Director for Research and Resources: The Forum on Education Abroad, Carlisle, PA, USA

Corresponding author: Amelia Dietrich, The Forum on Education Abroad, email: 


\section{Before COVID-19}

Months ago, when I first sat down to write this introduction, everything was as I was accustomed to it being. The title I drafted was "Where We've Been and Where We're Going: Education Abroad Research in a New Decade.” In what was to be a succinct piece, I planned to highlight the essential research published by Frontiers: The Interdisciplinary Journal of Study Abroad over its first 25 years as the only academic journal to focus exclusively on research related to education abroad experiences, which is to say, educational experiences that account for less than a full degree and take place outside the borders of a student's country of origin or the country where they are pursuing a degree at an institution of higher learning (The Forum on Education Abroad 2020b). I also planned to look ahead to the future of research in our field. The world has changed around me since then, and with it my thoughts about the future of education abroad, but my reflections on Frontiers' past contributions remain steady.

\section{State of the Art}

Indeed, Frontiers has long published the seminal works from which our field has derived focus, goals, support, strength, inspiration, and much more. While Dwyer's (2004) oft-cited article proclaimed that “more is better," and MedinaLopez-Portillo's (2004) found greater intercultural sensitivity correlated with longer program duration, these studies found counterpoint in Chieffo and Griffith's (2004) study that demonstrate that even short-term programs provide students gains in intercultural awareness and functional knowledge of geography and language that make such experiences worthwhile. Engle \& Engle (2003) helped our field establish a clearer classification system for education abroad programs that informs research on education abroad outcomes and helps practitioners market programs and set expectations for prospective student sojourners. Strategies, then, for maximizing the impact in all programs, especially shorter ones, have since abounded as Frontiers authors have tested mechanisms for successful pre-departure interventions (Vande Berg, ConnorLinton \& Paige 2009), strategies for encouraging and guiding student reflection (Pagano \& Rosselle 2009, Williams 2017, Savicki \& Price 2017, Hamilton, Rubin, Tarrant \& Gleason 2019, among others), and techniques to make use of instructor mentorship to foment student growth and development (Anderson, Lorenz \& White 2016, Niehaus et al. 2018). Articles published in Frontiers have explored perennial challenges to student well-being and safety, such as student alcohol use abroad (Pedersen et al. 2019), the impact of abroad experiences on student mental health (Bathke \& Kim 2016), and even whether or not the 
average American student can recognize a rip tide in the ocean (Houser et al. 2016), leading us towards a better understanding-informed by data, not just anecdote-of how students can be empowered to make better choices for themselves. Work published in the areas of regional studies and intercultural relations have pushed the field forward with strategies for building solidarity with diverse communities at home and abroad and encouraging students to do the same. Manuscripts published in Frontiers have laid the groundwork for the evidenced-based practice we have grown accustomed to in our field. This journal serves as a common source from which scholars, practitioners, and scholar-practitioners across fields as diverse as foreign languages, education, marine biology, business and marketing, career development, public health can draw vital information that will support their work on education abroad programs. It is also a place where these educators can publish important findings that for many years had no place to call home.

\section{Innovation}

Over the course of 25 years, trailblazers in the field built Frontiers into a professional and academically rigorous journal that has been leading the way to the wider professionalization of the field of education abroad. The journal has been an outlet for an ever-growing, complex, self-reflective, and challenging discourse among professionals about why and how we do this thing called education abroad in the first place and how we can make it better and help it reach more students and change more lives.

Frontiers has not shied away from complex and sensitive topics, publishing research not only on the influence of education abroad on students, but also on faculty and staff who work in the field, making room for critical examinations of the value of education abroad for higher education as an enterprise of learning and growth for all involved (Shallenberger 2015, Lucas 2009, Ellinghaus et al. 2019). The journal has explored religion as a powerful, undeniable facet of home and host cultures and the student experience (Elliott et al 2018). From the journal's very first article (Twombly 1995 on "Piropos and Friendship” on the experience of American women being catcalled while studying abroad in Costa Rica), long before it was a trending topic across campuses and associations of higher learning, Frontiers provided a platform for research on equity, diversity, inclusion, and intersecting identities (Sweeney 2013, Willis 2015, see also: 2019 Virtual Issue on Diversity and Inclusion in Education Abroad; 2020 Special Issue on Diversity, Equity, \& Inclusion in Education Abroad). The journal has even published essays and studies that have 
questioned the very assumptions on which the field of education abroad is based: Do students really grow-and in what ways-from education abroad, and how do we know (Wong 2015)? Is study abroad perpetuating colonial narratives and systems (Ogden 2008, Ficarra 2017)? All is done with the goal of creating a space and a shared body of knowledge around what education abroad is, who it benefits and who it hurts, and how we can strive always to improve it.

\section{Positioning Frontiers for a New Decade}

As you read this introduction on our new website, you will see some new features that will improve the experience for readers, authors, peer reviewers, and editors, and which will help to increase the visibility and reach of Frontiers publications.

- Abstracts are now published in multiple languages.

- All archival and forthcoming articles have digital object identifiers (DOIs).

- The web search functions are greatly improved.

- Our new website tracks view and download statistics that can be shared with authors and interfaces more effectively with Google Scholar and indices of scholarly work to better serve authors and readers.

I am pleased to announce an upcoming change in our editorial structure. We will be adding a new position for an editor who will work with me, while retaining an additional degree of editorial independence from The Forum on Education Abroad as publisher. Since joining The Forum family of publications in 2015, Frontiers editorial leadership has always been exclusively in the hands of a full-time Forum staff member. In keeping with industry standards and to ensure that Frontiers can continue to pursue publication of rigorous and interesting work without undue influence from Forum interests now and in the future, we are preparing to welcome a scholar to join us and take the lead on content selection. The new editor will help to make Frontiers even more cutting edge and more relevant than it already has been for our field.

While these are welcome changes, some things remain the same. The Editorial Board and The Forum on Education Abroad (our publisher) remain committed to keeping Frontiers online and open-access so that it can be read by scholars and practitioners of all nations and at all phases of their careers, regardless of institutional affiliation or socioeconomic status. It is particularly paramount that I highlight the journal's on-going commitment to pursuing a more inclusive 
and equitable approach to academic publishing and peer review. As an Editorial Board we are constantly seeking new ways to ensure that our submission and selection process isn't excluding rigorous and significant work because the authors have been trained in different scholarly cultures or writing conventions from our own, because they are writing in their second (or third, or nth) language, or because they are not professional "researchers" in the conventional sense of the word.

\section{After COVID-19}

When I sat down to write this piece early in 2020, I had foreseen a range of questions that the field would be tackling in the decade to come. The list was long. How can we forge further ahead on understanding the transformative impact of education abroad on students of all sorts? Are we satisfied with what we know about making education abroad inclusive and equitable for all students? Do we know enough about the impact education abroad has on the communities that receive foreign students and programs in the short- and longterm? Have we sufficiently explored the footprints that education abroad programming leaves behind on the natural environment? The economy? The sociocultural fabric of a place? Have we challenged ourselves as much as we should to face these questions head-on, even when they mean confronting longheld assumptions and ways of doing? Have we been brave enough to ask ourselves and our colleagues these questions even if the answers aren't what we want to hear...just yet? And I was going to welcome you into the new decade by imploring you to ask these tough questions and think up creative ways to tackle them and to send that research to Frontiers.

But then the world changed.

The novel coronavirus that began ravaging communities and healthcare systems in late 2019 has rocked our whole world and has certainly shaken the field of education abroad to its very core. By March 2020, as I was preparing to put the final touches on my original version of this piece, colleges and universities and independent education abroad organizations around the world were scrambling to bring students home as airports and borders closed and a tiny little germ scared us more than perhaps anything else ever has in the modern history of education abroad.

In early April 2020, as I write this, data collection efforts and plans for survival and recovery as a field are already underway in the form of program cancellation tracking and quick pivots to online learning models to keep 
international and intercultural exchange alive even when students aren't able to travel to far-off lands (The Forum on Education Abroad 2020a). This is a creative and resilient field, and it seems obvious that, as a profession, international education will do all it can to come out of this better and wiser, but in the meantime uncertainty abounds. Reduced enrollment is cutting budgets. A veritable army of road warriors and world travelers find themselves working from home while on quarantine. Careers are being interrupted (Redden 2020). The future of our field and of the higher education systems we support and connect are hard to picture.

For a while I felt like maybe I should skip this introduction all together. Take a moment of silence to mourn what we've lost. Honor the colleagues who have lost their jobs and may no longer be calling themselves international educators by the time the field rebounds (Wiley 2020). I found myself asking: What does it mean to be international educators at a time when people can't leave their homes, let alone cross national borders? What has this massive, haphazard shift to online learning and socializing via digital platforms taught us about our previous assumptions about the value of virtual exchange and about what is possible moving forward? Will anyone read this?

Then I read novelist Arundhati Roy's heartbreaking yet inspiring "The pandemic is a portal" (2020) and Rebecca Spang's (2020) proclamation that "The Revolution Is Under Way Already,” and I looked back on my notes for this introduction. I don't mean to trivialize their takes on larger social issues and international crises by appropriating them for our little corner of the professional sphere, but from this corner, our goal is to give students the scaffolding they need to be critical global citizens who work and vote and live within the context of the larger sociopolitical realities that COVID-19 has laid bare and the fertile ground for change is has left in its wake. Poverty, hunger, healthcare, immigration, the value of work and who is "essential." Through education abroad we aim to help students look past their bubble and understand these issues from multiple perspectives, to put themselves in the shoes of people around the world who may be very different from themselves, but who share the common trait of being human. By doing so, we hope that they will engage with these issues in a way that can do the world some good. Maybe COVID-19 has been a reality check to the privileged amongst us and among our students because it has pressed pause on a way of life we were taking for granted. It seems to me now that the path forward for education abroad and for its role in our larger world-which I always planned to shine a bit of light on through this piece-is even more important to welcome, to look forward to, to 
prepare for, to usher in as best we can, than it was when I first started writing this piece.

Most agree that the modern iteration of education abroad emerged from the world wars as a way to build understanding and goodwill across borders in the hope that it might help us avoid such a thing ever again (Hoffa 2007). Since then, conflicts and uprisings in particular regions and outbreaks of disease in others have at times pressed pause on study abroad to certain parts of the world. As a field, we have generally rebounded and then kept growing (Goodman 2020). While we can't know when this will be "over," if it ever really will be, we do know that in early 2020, the spread of an aggressive virus across the globe led to the unprecedented halt of what we've called study abroad for almost 100 years. Borders closed. Planes grounded. Students returned home. As a profession, we've never seen this before, and I sure we hope we'll never see it again. It is sobering and bewildering and traumatic. I don't want to underestimate the weight of all that.

\section{The Silver Lining}

This moment is also an opportunity. Future histories of our profession will cite this year as a turning point around which education abroad was transformed. We no longer have the long-held excuses for why we can't shift our practices. The way that we've always done things is already on an indefinite hiatus. Why not use this time to explore alternatives and seek improvement in the places where progress has been slow?

As a field, we proclaim commitment to these values: We value partnership over business transactions. Genuine relationships and community engagement are worth more to us than traditional tourism. We value culture with both a capital and a lowercase $\mathrm{C}$, the culture of fine arts and everyday life in equal measure. We want to "decolonialize" our field and our lessons and cease prioritizing certain sources or types of knowledge from certain kinds of people over others. We want the programs we offer our students to be more inclusive, the outcomes more equitable. We want to change their lives in bigger and better and more tangible ways. We want to reach more students and more diverse students. We want to teach those students that the value of studying in a far-off and unfamiliar place isn't just the people that live there or the nature that surrounds you, but both together. That we are all intertwined and interconnected and that through these international and intercultural experiences students build a worldview that values all of these ideals and the skillsets they'll need to pursue lives and careers that embody these values and advance our global society 
towards a more just world (The Forum, 2020c). Yet in areas of sustainability, diversity, equity, inclusion, decolonization, and so much more, many of us are still taking our first baby steps. Too often the inertia of "that's just how we've always done it" has stood in the way of making the paradigm shift that is needed.

We no longer have that excuse. By the time borders re-open and we feel safe being physically close to others again, the field of education abroad will have no choice but to reinvent itself. We are well on our way already.

So, it's ok to be taking it day-by-day during this time of self-isolation and collective unease, but if you can find the time or you welcome the distraction, I encourage you to let your mind wander. Think expansively. Use this quarantine as your cocoon, if you will. Now is the time to prepare for the reinvention of this field. How has this experience changed us? Are the virtual strategies we're pivoting to working? How can we blend the virtual and the in-person, the local and the global, in more meaningful ways that will serve us long after borders reopen? How can we prepare for the next time something catastrophic occurs? When we and our students start tiptoeing back on to planes again, how will we have made education abroad more inclusive, equitable, decolonized, indigenized, resilient, flexible_-in short_relevant? And what evidence will we have to know that is true? Now is as good a time as any to dig into this important work.

When you're ready to publish, Frontiers will be here to help you share it with the world.

\section{Acknowledgement}

Since I assumed leadership of this journal in 2018, several long-time contributors to Frontiers have moved on to their next adventures. To journal cofounder Tim Perkins, long-time Associate Editor Colin Ireland, and editorial board members Sheila Bayne and Chris Deegan, I extend my sincerest thanks. To all of the Editorial Board members I've worked with since 2015, thank you for your support, for asking tough questions, for the many laughs, for your vote of confidence, and for always pushing to make Frontiers a voice for our field and a resource to our colleagues around the world. Most importantly, thank you for creating and shaping Frontiers, and for leaving this little corner of academic inquiry better off than you found it. I am very grateful to Nancy Kanach, Mark Odenwelder, and Taylor Woodman for their thoughtful comments on this 
particular piece and for giving me the courage to publish it when I had my doubts.

\section{Author Biography}

Dr. Amelia Dietrich is the Managing Editor of Frontiers: The Interdisciplinary Journal of Study Abroad and Director for Research and Resources at The Forum on Education. She holds a Ph.D. in Spanish and Language Science from The Pennsylvania State University. She has written for academic and industry publications on topics including student health and safety abroad, education abroad best practices, the history of U.S. education abroad, bilingualism, codeswitching, and language processing.

\section{References}

Anderson, C. L., Lorenz, K., \& White, M. (2016). Instructor Influence on Student Intercultural Gains and Learning during Instructor-Led, Short-Term Study Abroad. Frontiers: The Interdisciplinary Journal of Study Abroad, 28(1), 1-23. https://doi.org/10.36366/frontiers.v28i1.377

Bathke, A., \& Kim, Y.-H. (2016). Keep Calm and Study Abroad: The Effect of Learning Abroad on Student Mental Health. Frontiers: The Interdisciplinary Journal of Study Abroad, 27(1), 1-16. https://doi.org/10.36366/frontiers.v27i1.371

Chieffo, L., \& Griffiths, L. (2004). Large-Scale Assessment of Student Attitudes after a ShortTerm Study Abroad Program. Frontiers: The Interdisciplinary Journal of Study Abroad, 10(1), 165-177. https://doi.org/10.36366/frontiers.v10i1.140

Contreras Jr., E., López-McGee, L., Wick, D., \& Willis, T. (2019). Introduction: A Virtual Issue on Diversity and Inclusion in Education Abroad. Frontiers: The Interdisciplinary Journal of Study Abroad,31(Virtual), https://doi.org/10.36366/frontiers.v31iVirtual.451

Contreras Jr., E., López-McGee, L., Wick, D., \& Willis, T. Y. (2020). Introduction: Special Issue on Diversity, Equity, and Inclusion in Education Abroad. Frontiers: The Interdisciplinary Journal of Study Abroad,32(1), 1-11. https://doi.org/10.36366/frontiers.v32i1.431

Dwyer, M. M. (2004). More Is Better: The Impact of Study Abroad Program Duration. Frontiers: The Interdisciplinary Journal of Study Abroad, 10(1), 151-164. https://doi.org/10.36366/frontiers.v10i1.139

Ellinghaus, K., Spinks, J., Moore, G., Hetherington, P., \& Atherton, C. (2019). Learning to Teach in the Field: Five Professors Tell How Running an Overseas Study Tour Improved Their Classroom Teaching. Frontiers: The Interdisciplinary Journal of Study Abroad, 31(1), 169-189. https://doi.org/10.36366/frontiers.v31i1.448

Elliott, T. L., Hyndman III, W. T., Larkin, N., Scarboro, D., \& Woolf, M. (2018). For God's Sake: Religion and Study Abroad. Frontiers: The Interdisciplinary Journal of Study Abroad, 30(1), i-iv. https://doi.org/10.36366/frontiers.v30i1.398

Engle, L., \& Engle, J. (2003). Study Abroad Levels: Toward a Classification of Program Types. Frontiers: The Interdisciplinary Journal of Study Abroad, 9(1), 1-20. https://doi.org/10.36366/frontiers.v9i1.113 
Ficarra, J. M. (2017). Curating Cartographies of Knowledge: Reading Institutional Study Abroad Portfolio as Text. Frontiers: The Interdisciplinary Journal of Study Abroad, 29(1), 1-14. https://doi.org/10.36366/frontiers.v29i1.382

Goodman, A. (2020). U.S. Study Abroad During Health Crises. IIE Interactive. https://mailchi.mp/iie/iieinteractive-255029?e=9b9ec9aa60

Hamilton, A., Rubin, D., Tarrant, M., \& Gleason, M. (2019). Digital Storytelling as a Tool for Fostering Reflection. Frontiers: The Interdisciplinary Journal of Study Abroad, 31(1), 59-73. https://doi.org/10.36366/frontiers.v31i1.443

Hoffa, William W. (2007). A History of U.S. Study Abroad: Beginnings to 1965. The Forum on Education Abroad.

Houser, C., Brander, R., Brannstrom, C., Trimble, S., \& Flaherty, J. (2016). Case Study of Rip Current Knowledge amongst Students Participating in a Study Abroad Program. Frontiers: The Interdisciplinary Journal of Study Abroad, 28(1), 42-60. https://doi.org/10.36366/frontiers.v28i1.379

Lucas, J. (2009). Over-stressed, Overwhelmed, and Over Here: Resident Directors and the Challenges of Student Mental Health Abroad. Frontiers: The Interdisciplinary Journal of Study Abroad, 18(1), 187-216. https://doi.org/10.36366/frontiers.v18i1.261

Medina-López-Portillo, A. (2004). Intercultural Learning Assessment: The Link between Program Duration and the Development of Intercultural Sensitivity. Frontiers: The Interdisciplinary Journal of Study Abroad, 10(1), 179-200. https://doi.org/10.36366/frontiers.v10i1.141

Niehaus , E., Reading , J., Nelson , M. J., Wegener , A., \& Arthur , A. (2018). Faculty Engagement in Cultural Mentoring as Instructors of Short-Term and Semester Study Abroad Programs. Frontiers: The Interdisciplinary Journal of Study Abroad, 30(2), 77-91. https://doi.org/10.36366/frontiers.v30i2.413

Ogden, A. (2007). The View from the Veranda: Understanding Today's Colonial Student. Frontiers: The Interdisciplinary Journal of Study Abroad, 15(1), 35-56. https://doi.org/10.36366/frontiers.v15i1.215

Pagano, M., \& Roselle, L. (2009). Beyond Reflection: Refraction and International Experiential Education. Frontiers: The Interdisciplinary Journal of Study Abroad, 18(1), 217-229. https://doi.org/10.36366/frontiers.v18i1.263

Redden, E. (2020, March) Study Abroad Provider Cuts More Than 600 Jobs. Insider Higher Ed. https://www.insidehighered.com/quicktakes/2020/03/30/study-abroad-provider-cutsmore-600-jobs

Roy, Arundhati. (2020, April). The pandemic is a portal. Financial Times. https:/www.ft.com/content/10d8f5e8-74eb-11ea-95fe-fcd274e920ca

Savicki, V., \& Price, M. V. (2017). Components of Reflection: A Longitudinal Analysis of Study Abroad Student Blog Posts. Frontiers: The Interdisciplinary Journal of Study Abroad, 29(2), 51-62. https://doi.org/10.36366/frontiers.v29i2.392

Shallenberger, D. (2015). Learning from Our Mistakes: International Educators Reflect. Frontiers: The Interdisciplinary Journal of Study Abroad, 26(1), 248-263. https://doi.org/10.36366/frontiers.v26i1.369

Smucker, S., Pedersen, E. R., LaBrie, J. W., D’Amico, E. J., Farris, C., Klein, D. J., \& Griffin, B. A. (2019). There and Back Again.Safely: Examining Students' Reports of Substance Use and Sexual Assault Prevention Program Receipt Prior to Departure Abroad. Frontiers: The Interdisciplinary Journal of Study Abroad, 31(2), 51-62. https://doi.org/10.36366/frontiers.v31i2.454 
Spang, Rebecca L. (2020, April). The Revolution Is Under Way Already. The Atlantic. https://www.theatlantic.com/ideas/archive/2020/04/revolution-only-gettingstarted/609463/

Sweeney, K. (2013). Inclusive Excellence and Underrepresentation of Students of Color in Study Abroad. Frontiers: The Interdisciplinary Journal of Study Abroad, 23(1), 1-21. https://doi.org/10.36366/frontiers.v23i1.326

The Forum on Education Abroad. (2020a). COVID-19 Program Status Tracker. Retrieved from https://www.forumea.org/COVID-19-program-status-tracker

The Forum on Education Abroad. (2020b). Glossary. The Forum on Education Abroad. https://forumea.org/resources/glossary/?letter $=\mathrm{E}$

The Forum on Education Abroad. (2020c). Standards of Good Practice for Education Abroad, $6^{\text {th }}$ edition. The Forum on Education Abroad. https://www.forumea.org/standards

Twombly, S. B. (1995). Piropos and Friendships: Gender and Culture Clash in Study Abroad. Frontiers: The Interdisciplinary Journal of Study Abroad,1(1), 1-27. https://doi.org/10.36366/frontiers.v1i1.2

Vande Berg, M., Connor-Linton, J., \& Paige, R. M. (2009). The Georgetown Consortium Project: Interventions for Student Learning Abroad. Frontiers: The Interdisciplinary Journal of Study Abroad, 18(1), 1-75. https://doi.org/10.36366/frontiers.v18i1.251

Wiley, A. (2020, April). A Moment of Silence for International Education. LinkedIn. https://www.linkedin.com/pulse/moment-silence-international-education-andreawiley/?trackingId=CtvWJhqFP\%2B17ndflchw02A\%3D\%3D

Williams, T. R. (2017). Using a PRISM for Reflecting: Providing Tools for Study Abroad Students to Increase their Intercultural Competency. Frontiers: The Interdisciplinary Journal of Study Abroad, 29(2), 18-34. https://doi.org/10.36366/frontiers.v29i2.390

Willis, T. Y. (2015). “And Still We Rise...”: Microaggressions and Intersectionality in the Study Abroad Experiences of Black Women. Frontiers: The Interdisciplinary Journal of Study Abroad, 26(1), 209-230. https://doi.org/10.36366/frontiers.v26i1.367

Wong, E. D. (2015). Beyond "It was Great"? Not so Fast!. Frontiers: The Interdisciplinary Journal of Study Abroad, 26(1), 121-135. https://doi.org/10.36366/frontiers.v26i1.362 